\title{
Evaluation of Bio-toxicity Removal by Two-Stage Membrane Bioreactor for Landfill Leachate Treatment
}

\author{
V. Boonyaroj ${ }^{1}$, C. Chiemchaisri ${ }^{2 *}$, W. Chiemchaisri ${ }^{2}$ \& K. Yamamoto ${ }^{3}$ \\ ${ }^{1}$ International Postgraduate Programs in Environmental Management/ Center of Excellence for Environmental \\ and Hazardous Waste Management (EHWM), Chulalongkorn University, Bangkok, Thailand \\ ${ }^{2}$ Department of Environmental Engineering/National Center of Excellence for Environmental and Hazardous \\ Waste Management, Faculty of Engineering, Kasetsart University, Bangkok 10900, Thailand \\ ${ }^{3}$ Environmental Science Center, University of Tokyo, Tokyo 113, Japan
}

\begin{abstract}
Two-stage membrane bioreactor was applied to the treatment of municipal solid waste landfill leachate. This study aimed to evaluate the toxicity of treated leachate by this system. Bio-toxicity (acute and geno-toxicity) were conducted using $O$. niloticus and C. carpio. The lethal concentrations $\left(\mathrm{LC}_{50}\right)$ of selected species exposed to raw leachate and treated leachate were investigated. Comet assay was utilized for evaluation of geno-toxicity potential of raw and treated leachate using carried out at the $10^{\text {th }}$ percentile of lethal concentration $\left(\mathrm{LC}_{10}\right)$ that obtained from the acute toxicity test. The relationship between pollutant concentrations i.e., $\mathrm{NH}_{3}$, $\mathrm{COD}$ and mortality were analyzed on Finney's probit analysis. The results found that ammonia was the principal pollutants causing toxicity in landfill leachate. Nevertheless, toxicity effect between ammonia and organic concentrations was also observed. The corresponding ammonia concentration causing 50\% mortality of $C$. carpio and O. niloticus after 96 hour exposure were 2.3-2.6 and 2.2-2.5 mg/l respectively. The sensitivity test of geno-toxicity effect at the level of DNA damage show that $O$. niloticus was considerably more sensitive to leachate. The membrane bioreactor system helps reducing toxic organic compounds and bio-toxicity on living organisms.
\end{abstract}

Keywords: Membrane bioreactor, bio-toxicity, geno-toxicity, comet assay, mortality

\subsection{INTRODUCTION}

Two-stage membrane bioreactor (MBR) consists of anoxic and aerobic reactor connected in series. The first reactor is anoxic tank in which inclined tube separator was installed. The second reactor is aerobic tank where submerged membrane modules were used for separation of treated water from mixed liquor. This type of membrane bioreactor has been applied successfully to the treatment of high-strength wastewater and without excess sludge production. It was

*Corresponding to: C. Chiemchaisri (email: fengccc@ku.ac.th) also recently applied for the treatment of high organic and nitrogen compounds in partially stabilized leachate [1, 2]. Even though major pollutants such as organic substances in terms of BOD, COD and nutrients in leachate could be efficiently removed in MBR, it is still a need to be considered if the treated water is safe to aquatic lives when it is discharged in to natural environment as several micro-pollutants such as aromatic hydrocarbons, haloganated hydrocarbons, phenolic compounds and phthalates [3] can cause detrimental effect to living organisms even their presence at low concentrations. The bioassays using bacteria 
and algal species, activated sludge respiration inhibition test, toxicity testing on invertebrates and fishes can be used to characterize the toxicity of landfill leachate to integrate the biological effect of all its constituents. Although the toxicity testing using bacteria was the most popularly used method, it was found to have a lack of sensitivity. Meanwhile, the toxicity testing with fish was particularly sensitive to landfill leachate but more research in this area is still needed [4].

The toxicity of landfill leachate has been assessed by several researchers using a number of different living organisms, including luminescent bacteria Vibrio fischeri, aquatic vertebrates (fishes). The most popular bioassays are with aquatic invertebrates (especially crustaceans) and the different test organisms have been observed in most studies [3, 5-7]. Both chemical analyses and bioassays can be used to assess and quantify the toxicity of treated leachate after leachate treatment processes.

\subsection{MATERIAL AND METHODS}

In this experiment, the bio-toxicity determination was performed according to according to previous described procedures [7]. The acute and genotoxicity of leachate samples were conducted using $O$. niloticus and C. carpio to study the toxicity of leachate and treated water of two-stage MBR system. The two-stage MBR consists of first stage anoxic reactor of $1 \mathrm{~m} 3$ volume followed by aerobic reactor of the same volume. Six modules of hollow fiber membrane (PE material, 0.4 micron pore size) were provided for solid-liquid separation in the aerobic reactor. The feeding rate of leachate was controlled at a $2 \mathrm{~m}^{3} / \mathrm{d}$ so that hydraulic retention time in the MBR was fixed at 1 day. The dissolved oxygen of 3-4 mg/l and the mixed liquor suspended solids (MLSS) of 10-12 g/l were maintained in the aerobic reactor.

Leachate used in the MBR system was prepared from mixing fresh and stabilized leachate at a mixing ratio of approximately 1: 10. Fresh leachate was obtained directly from municipal solid waste collection trucks that arrived at the disposal site. Stabilized leachate was obtained from the storage pond located inside the disposal site. The pond received leachate drained out from the closed landfill cells. The retention time of leachate in the storage pond was several years. The mixed leachate contained COD and $\mathrm{NH}_{3}-\mathrm{N}$ concentrations of 9,000-9,620 mg/l and $112-174 \mathrm{mg} / \mathrm{l}$ respectively. Electrical conductivity (EC) of leachate was 23.2-26.0 $\mathrm{mS} / \mathrm{cm}$.

\subsection{Acute Testing}

The fish species was conducted using $O$. niloticus and $C$. carpio obtained from a local breeder and transported immediately to the laboratory in appropriately aerated plastic bags. In the laboratory, fish species were kept separately in 120 liter glass aquaria $(0.40 \mathrm{~m}$ width, 0.75 $\mathrm{m}$ length, and $0.45 \mathrm{~m}$ depth) containing dechlorinated tap water. They were acclimated for 14 days with continuous aeration and the water was renewed every 3 days. The photo-period was set at 12:12 hour (light:dark) condition during the entire experiment. Care is taken in order to keep the mortality rate less than 5\% in the last 5 days before the experiments was started. During this period, no food was fed to the fish and water qualities in the aquaria were closely monitored to avoid accumulation of wastes and other toxic compounds in water.

In triplicate, 10 adult fishes were placed in water sample that are diluted to five dilutions, corresponding to 50-2,000 $\mathrm{mgCOD} / \mathrm{l}$ and 2-12 $\mathrm{mgNH}_{3} /$ l. These concentration ranges were selected as they were found to provide fish mortality response ranged from 0 to $100 \%$ based on our previous studies [7]. The exposure test was carried out at temperature room of $28.1^{\circ} \mathrm{C}$ for 96 hour. The number of dead fish was recorded every 24 hour. In triplicate, non-exposed fish were observed in fresh water under same conditions as mentioned above as control experiment. The 96 hour $\mathrm{LC}_{50}$ for fish species and its 95\% confident limits were calculated using probit transformation of the mortality data, and the relationship between pollutant concentrations, i.e. $\mathrm{NH}_{3}$ and COD and mortality ratio was developed based on experimental data. The program based on Finneys Probit Analysis method using SPSS (version 16.0) for Windows. 


\subsection{Geno-toxicity Testing}

The analyses of $C$. carpio and $O$. niloticus DNA strand breaks were performed which 10 fish were exposed to 20 liter of water sample that are diluted at 10 percentage of lethal concentration $\left(\mathrm{LC}_{10}\right)$ with dechlorinated tap water for 7 days under conditions of 12:12 hour light:dark. The concentration was set based on our previous study which found it provided low fish mortality but clear geno-toxicity condition [7]. In triplicate, non-exposed fish are observed in fresh water under same conditions to be control experiment. Blood of fish are collected at 0,7 days all of the experiment. Peripheral blood of fish was collected from a caudal vein using $1 \mathrm{ml}$ heparinized syringe. A $15 \mu \mathrm{l}$ of blood is diluted with $1 \mathrm{ml}$ of chilled phosphate-buffered saline (PBS). Slide preparation, $2.5 \mu$ l of diluted sample were mixed with $50 \mu \mathrm{L}$ of PBS and $50 \mu \mathrm{l}$ of $0.5 \%$ LMP agarose in micro-centrifuge tube at $37-40^{\circ} \mathrm{C}$ and layered on comet slide, and after this layer were solidified at $4^{\circ} \mathrm{C}$. The slides were immersed in the alkalilysis buffer (1\% sodium sarcosinate, $2.5 \mathrm{M} \mathrm{NaCl}, 100 \mathrm{mM}$ $\mathrm{Na}_{2}$ EDTA, $10 \mathrm{M}$ Tris HCl, pH 10, 10\% DMSO, $1 \%$ Triton $\mathrm{X}-100$ ) for $3-24$ hour at $4^{\circ} \mathrm{C}$. Then, the slides were placed in alkaline electrophoresis buffer $(10 \mathrm{~N} \mathrm{NaOH}, 200 \mathrm{mM}$ EDTA $5 \mathrm{ml}$, $\mathrm{pH}>13$ ) for $10 \mathrm{~min}$. Electrophoresis was performed at $15 \mathrm{~V}, 250 \mathrm{~mA}$ for $25 \mathrm{~min}$ at $4^{\circ} \mathrm{C}$. The slides were then neutralized with neutralization buffer (tris-hydroxymethylaminomethane $48.5 \mathrm{~g}, \mathrm{pH} 7.5$ ) for $20 \mathrm{~min}$. After that, slides were immerged in ethyl alcohol for $5 \mathrm{~min}$ and pure water for $10 \mathrm{~min}$. It was dried by placement on hot plate at $50^{\circ} \mathrm{C}$

Finally, the cells were stained with $50 \mathrm{~mL}$ of SYBER safe ${ }^{\mathrm{TM}}$ Green. Comet images are analyzed using a fluorescence microscope, $515 \mathrm{~nm}$ and barrier filter, $590 \mathrm{~nm}$ (magnification 10.) to determine the sufficient cell dispersed. A total of 100 cells from each slide were randomly scored and analyzed using an image analysis system (Tritek Comet Score Freeware Version 1.5). The comet parameter, i.e. percent tail DNA (\% tail DNA $=100$ - head DNA) as determined by the software was used for quantification of DNA damage.
Bivariate relationships between physicochemical parameters (COD, unionized ammonia or UIA, pH, and EC), and mortality of tested organisms using Pearson correlation and the association between $\mathrm{LC}_{50}$ and physicochemical parameters was performed using multiple linear regressions. For the statistical analysis, significance was evaluated at $\mathrm{P}<0.01$ and $\mathrm{P}<0.05$.

\subsection{RESULTS}

\subsection{Acute Toxicity Determinations}

\subsubsection{LC $_{50}$ Value Determination}

The lethal concentrations $\left(\mathrm{LC}_{50}\right)$ of selected fish species exposed to MBR influent leachate and MBR treated leachate. Table 1 shows that $\mathrm{LC}_{50}$ for raw leachate were $1.94 \%(\mathrm{v} / \mathrm{v})$, and $2.02 \%$ (v/v) for O. niloticus and C. carpio whereas those of treated water were $19.54 \%(\mathrm{v} / \mathrm{v})$, and $17.57 \%$ $(\mathrm{v} / \mathrm{v})$ respectively. This experiment shown that the 96 hour $\mathrm{LC}_{50}$ of ammonia causing acute toxicity on $C$. carpio and $O$. niloticus were found to be 2.3-2.6 mg/l, and 2.2-2.5 mg/l, respectively.

Table $1 \mathrm{LC}_{50}$ values of MBR influent and MBR treated leachate on tested species

\begin{tabular}{|c|c|c|c|}
\hline \multirow[t]{2}{*}{ Fish species } & \multirow{2}{*}{$\begin{array}{c}\mathrm{LC}_{50} * \\
\text { (\%dilution) }\end{array}$} & \multicolumn{2}{|c|}{$\begin{array}{l}\text { Corresponding } \\
\text { pollutant } \\
\text { concentrations* }\end{array}$} \\
\hline & & $\begin{array}{l}\text { COD } \\
(\mathrm{mg} / \mathrm{l})\end{array}$ & $\begin{array}{c}\mathrm{NH}_{3^{-}} \\
\mathrm{N}(\mathrm{mg} / \mathrm{l})\end{array}$ \\
\hline $\begin{array}{l}\text { MBR influen } \\
\text { O. niloticus }\end{array}$ & $\begin{array}{l}1.94 \\
\quad(1.81-2.09)\end{array}$ & $\begin{array}{c}187 \\
(173-201)\end{array}$ & $\begin{array}{c}2.3 \\
(2.2-2.5)\end{array}$ \\
\hline C. carpio & $\begin{array}{c}2.02 \\
(1.88-2.18)\end{array}$ & $\begin{array}{c}194 \\
(180-209)\end{array}$ & $\begin{array}{c}2.4 \\
(2.3-2.6)\end{array}$ \\
\hline $\begin{array}{l}\text { MBR treated } \\
\text { O. niloticus }\end{array}$ & $\begin{array}{c}19.54 \\
(18.47-20.66)\end{array}$ & $\begin{array}{c}225 \\
(212-238)\end{array}$ & $\begin{array}{c}4.9 \\
(4.6-5.2)\end{array}$ \\
\hline C. carpio & $\begin{array}{c}17.57 \\
(16.41-18.80)\end{array}$ & $\begin{array}{c}202 \\
(189-216)\end{array}$ & $\begin{array}{c}4.4 \\
(4.1-4.7)\end{array}$ \\
\hline
\end{tabular}

* Average (range) values, no. of samples $=33$.

Note: Value in bracket denotes dilution and corresponding concentration ranges for $95 \%$ confidence limit 

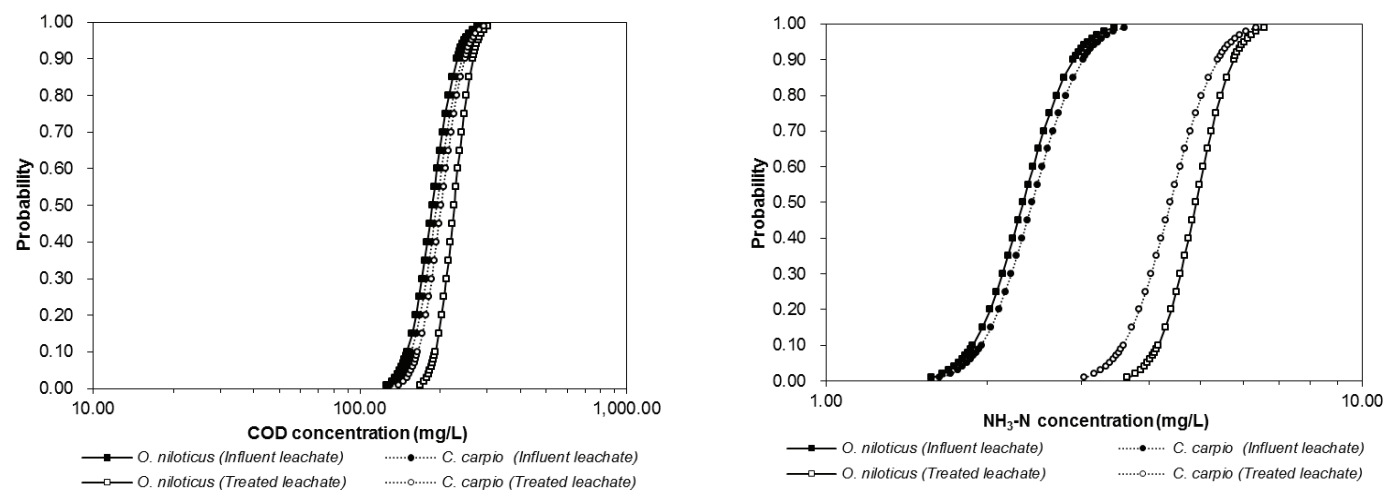

Figure 1 Effect of $\mathrm{COD}$ and $\mathrm{NH}_{3}-\mathrm{N}$ concentration in leachate on mortality of living organisms

The effect of $\mathrm{COD}$ and $\mathrm{NH}_{3}-\mathrm{N}$ concentration in leachate on mortality of living organisms are shown in Figure 1. The influent COD concentrations were ranging between 9,000 and $9,620 \mathrm{mg} / \mathrm{l}$ whereas BOD concentrations varied from 6,100 to $7,542 \mathrm{mg} / \mathrm{l}$ and $\mathrm{NH}_{3}-\mathrm{N}$ concentrations were between 112 and $174 \mathrm{mg} / \mathrm{l}$. After the treatment, the effluent contained COD, BOD, and $\mathrm{NH}_{3}-\mathrm{N}$ concentrations were 880-1,600 $\mathrm{mg} / \mathrm{l}, 110-240 \mathrm{mg} / \mathrm{l}$, and 3-25 mg/l, respectively. Based on acute toxicity determination, higher $\mathrm{LC}_{50}$ values were obtained from the test using treated water as compared to influent leachate and these results indicated that the biotoxicity of leachate was reduced by MBR treatment.

This observation may imply that there was a combined toxic effect between ammonia and other organic compounds present in leachate. Therefore, the removal of some toxic organic compounds during biological treatment using MBR helped reducing the bio-toxicity of leachate in this study. This result shows a significant reduction in bio-toxicity of leachate after twostage MBR system that similar to our previous study [7]. Some differences in bio-toxicity effect were observed among the tested species. Previous researches have shown the evaluation of acute toxicity of landfill leachate from three different landfills in Malaysia to common carp (Cyprinus carpio) and reported 96 hour $\mathrm{LC}_{50}$ values of $1.1-3.82 \%(\mathrm{v} / \mathrm{v})$. The 96 hour $\mathrm{LC}_{50}$ for municipal solid waste landfill leachate on fingerlings of Clarias Gariepinus was $36.6 \%$ (v/v). The 48 hour $\mathrm{LC}_{50}$ for leachates of ten sampling from municipal solid waste landfills on Artemia franciscana were $3.2 \%$ and $39.3 \%[5,6]$. Compared to previous described results, it was found that the influent leachate in this study provided the same toxicity level to local fish species as the Malaysian landfills but more toxic condition to living organisms than other studies. The treated water was found to contain much lower toxicity than influent leachate but post-treatment using reverse osmosis would be still required to remove the bio-toxicity completely [7].

\subsubsection{Data Analyses between Acute Toxicity and Chemical Pollutants}

The experimental results also indicated the correlation coefficient and significant differences between mortality of tested organisms and physicochemical parameters which were UIA, $\mathrm{COD}, \mathrm{pH}$, and EC. The correlation coefficient between mortality, and COD concentration values of $O$. niloticus, and C. carpio were 0.708 , and 0.808 respectively, whereas those of UIA values were 0.509 , and 0.572 respectively. The significant levels, and COD concentration values of $O$. niloticus, $C$. carpio were found to be 0.000 and 0.000 respectively, whereas those for UIA concentration values were 0.002 , and 0.000 respectively. The result indicated that mortality of O. niloticus, and C. carpio was strongly correlated $(\mathrm{P}<0.01)$ with ammonia and COD concentrations in leachate. For other parameters, EC was correlated with mortality of $O$. niloticus, and $C$. carpio with coefficient values of 0.256 , and 0.307 respectively. The significant levels were found 
to be 0.000 , and 0.001 respectively. A negative correlation were found between mortality and $\mathrm{pH}$ values of $O$. niloticus, and C. carpio with the value of $-0.132(0.001)$ and $-0.138(0.000)$.

This result suggests that UIA have direct relationship to toxicity and their concentrations increased the mortality of $C$. carpio, and $O$. niloticus with high sensitivity. In term of COD, their concentrations were also sensitively affecting the mortality of $O$. niloticus. Previous research [8] mentioned that ammonia was the main cause of the toxicity measured in the biotoxicity determination. Nevertheless, the toxicity in landfill leachate may depend on other several factors especially with the presence of toxic organic compounds [7]. It was also previously mentioned that the geno-toxicity test found that organic compounds in leachate may cause the mutagenic activity [3].

\subsection{Geno-toxicity Determination}

\subsubsection{Level of DNA Damage}

The comet assay was utilized as biomarker of the geno-toxicity potential of the raw and treated leachate. During the determination of genotoxicity, the leachate samples were diluted to

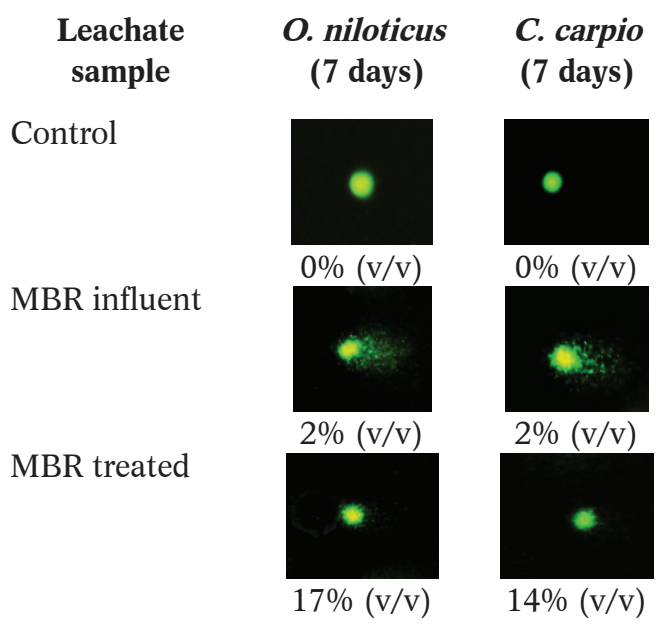

Figure 2 DNA damage appearances of comet in peripheral erythrocytes of fish species (O. niloticus and C.carpio) as a result of MBR influent leachate and MBR treated leachate at $\mathrm{LC}_{10}$
$10 \%$ percent of lethal concentration $\left(\mathrm{LC}_{10}\right)$, on fish species to ensure lower mortality rate. Figure 2 shows the DNA damage appearances of comet in peripheral erythrocytes of $O$. niloticus and $C$. carpio after their exposure to influent leachate and MBR treated leachate.

Level of DNA damage was analyzed using image analysis on 100 cells per sample. After the exposure period for 7 days, the DNA damages in fish blood cells were determined as compared to those of control experiment. A reduction of percentage of DNA damage for treated water as compared to influent leachate was clearly observed for both fish species as shown in Figure 3. Nevertheless, this type of DNA damage is possibly reversible as observed in environmental monitoring studies. After a recuperation period under non-polluted conditions, the degree of DNA percentage could be reduced reflecting the reversibility and non-persistence of such damage.

The DNA strand breaks, particularly as measured by the comet assay, act as a biomarker of mutagenicity in fish and other aquatic species. They also emphasized that this approach should be combined with the use of other biomarkers such as acute toxicity as described earlier to confirm the toxicity effect both under their

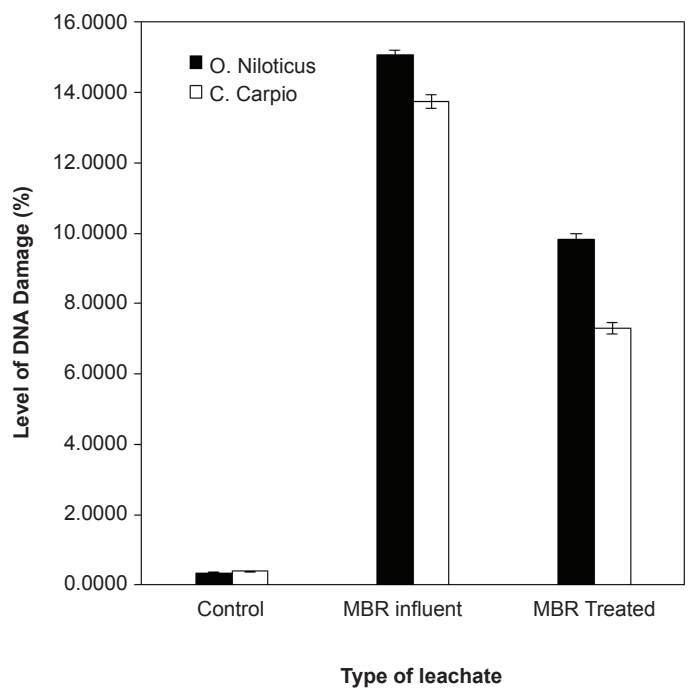

Figure 3 Level of DNA damage at 7 days of MBR influent leachate and MBR treated leachate $(\%)$ on fish species 
exposure to high and low concentrations of pollutants. In term of sensitivity between the tested species, the results showed that the \%DNA damage values of $O$. niloticus were higher than $\%$ DNA damage of $C$. carpio, demonstrating that $O$. niloticus was considerably more sensitive.

\subsubsection{Data Analyses between DNA Damage and Chemical Pollutants}

The significant relationship between DNA damage at $7^{\text {th }}$ day exposure and pollutant concentrations including, COD, UIA, pH, and EC was not clearly observed. It is possible that DNA damage may not correlate well with those parameters at this short exposure period. In order to confirm their effect, longer term experiment of mutagenicity/genotoxicity on fish species needs to be investigated. In previous study using leachate collected from ten Danish landfills, it was found that the leachates were mutagenic after pre-concentration, and the authors suggested that XOCs in leachate caused those mutagenic activities [9]. Base on multiple geno-toxicity tests of leachate from MSW landfills, it is suggested that landfill leachate may contain a large variety of organic compounds that are acutely and chronically toxic, and these leachate toxicity remains largely unknown.

\subsection{CONCLUSIONS}

The landfill leachate may contain a large variety of organic compounds that are acutely and chronically toxic and leachate toxicity remains largely unknown. This experiment demonstrates a superior performance of MBR regarding the removal of basic water quality parameters in term of $\mathrm{COD}$ and $\mathrm{NH}_{3}-\mathrm{N}$. The removal of toxic organic compounds in MBR also helped reducing leachate bio-toxicity on living organisms. Both chemical analysis and bioassays can be used to assess and quantify the toxicity of treated leachate after leachate treatment processes.

This result suggests that UIA have a direct relationship to toxicity, it is increase the sensitivity of $C$. carpio and $O$. niloticus respectively. The comet assay was utilized as biomarker of the genotoxic potential of the raw and treated leachate. The level of DNA damage was analyzed using image analysis on 100 cells per sample. The sensitivity of tested species, the result shows that the \%DNA damage values of $O$. niloticus were higher than \%DNA damage of $C$. carpio and demonstrated that $O$. niloticus was considerably more sensitive. This research provided a significant reduction in bio-toxicity of leachate after two-stage membrane bioreactor system.

\section{ACKNOWLEDGMENTS}

The authors would like to express their appreciation to Japan International Cooperation Agency (JICA) for providing research fund through Research and Development for Water Reuse Technology in Tropical Regions (WaterIntro) project.

\section{REFERENCES}

[1] Chiemchaisri, C., Chiemchaisri, W., Nindee, P., Chang, C. Y. and Yamamoto, K. 2011. Treatment performance and microbial characteristics in two-stage membrane bioreactor applied to partially stabilized leachate. Water Science and Technology. 64(5): 1064-1072.

[2] Xing, C. H., Yamamoto, K. and Fukushi, K. 2006. Performance of an inclined-plate membrane bioreactor at zero excess sludge discharge. Journal of Membrane Science. 275: 175-186.

[3] Kjeldsen, P., Barlaz, M. A., Rooker, A. P., Baun, A., Ledin, A. and Christensen, T. H. 2002. Present and long-term composition of MSW landfill leachate: a review. Critical Reviews in Environmental Science and Technology. 32: 297-336.

[4] Thomas, D. J. L., Tyrrel, S. F., Smith, R. and Farrow, S. 2009. Bioassays for the evaluation of landfill leachate toxicity. Journal of Toxicity and Environmental Health, Part B: Critical Reviews. 12(1): 83-105.

[5] Olivero-Verbel, J., Padilla-Bottet, C. and De la Rosa, O. 2008. Relationships between 
Physicochemical Parameters and the Toxicity of Leachates from a Municipal Solid Waste Landfill. Ecotoxicology and Environmental Safety. 70: 294-299.

[6] Oshode, O. A., Bakare, A. A., Adeogun, A. O., Efuntoye, M. O. and Sowunmi, A. A. 2008. Ecotoxicological Assessment Using Clarias Gariepinus and Microbial Characterization of Leachate from Municipal Solid Waste Landfill. International Journal of Environmental Research. 2(4): 391-400.

[7] Theepharaksapan, S., Chiemchaisri, C., Chiemchaisri, W. and Yamamoto, K. 2011. Removal of pollutants and reduction of biotoxicity in a full scale chemical coagulation and reverse osmosis leachate treatment system. Bioresource Technology. 102: 53815388.

[8] Clement, B., C. Delolme, T. Winiarski and Y. Bouvet. 1993. The Risk of Contamination by Leachates of Freshwater Ecosystems. Proceedings of the $4^{\text {th }}$ International Symposium on Landfill. Margherita di Pula, 1155-1166.

[9] Baun, A., Ledin, A., Reitzel, L. A., Bjerg, P. L. and Christensen, T. H. 2004. Xenobiotic organic compounds in leachates from ten Danish MSW landfills-chemical analysis and toxicity tests. Water Research. 38: 3845-3858. 